\title{
FORLAGET POLITICA
}

udgiver videnskabelige arbejder og undervisningsmateriale i statskundskab og inden for tilgrænsende områder.

Hidtil er udkommet:

Informationssystemer $i$ den offentlige forvaltning. Af Mogens Brabrand Jensen. 1974. Genoptrykt 1976. 200 s. 35,00 kr. incl. moms. Borger og kommune. Lang̊. Af ole Nørgaard Madsen, Poul Meyer og Søren Winter. 1976. Udsolgt.

Politisk integrationsteori. Redigeret af Carsten Lehmann Sørensen. 1976. $200 \mathrm{~s} .40,00 \mathrm{kr}$. incl. moms.

Festskrift til Erik Rasmussen. 1977. $340 \mathrm{~s} .50,00 \mathrm{kr}$. incl. moms. Tekster til historisk forskningsteknik. Redigeret af Jørgen Elklit m.fl. 2. ændrede udgave. 1977. 50,00 kr. incl. moms.

Offentlig forvaltning i Danmark. Af Poul Meyer, Georg Vedel-Smith, Ole Nфrgaard Madsen og Finn Bruun. 1977. $227 \mathrm{~s} .50,00 \mathrm{kr}$. incl. moms.

Studier i kommunalpolitik. Beskrivelse, analyse og vurdering af servicevariationer. Af Carl-Johan Skovsgaard, Søren Rohde, Poul Erik Mouritzen, Ulrik Thomassen og Peer Jacobsen. 1977. Let revideret 2. udgave 1978. $148 \mathrm{~s} .50,00 \mathrm{kr}$. incl. moms.

Offentlig virksomhedsledeise. Kompendier i statskundskab. Af Finn Bruun. 1977. 35 s. Udsolgt.

Kulturel velfard som politisk mål. Af Steen Bengtsson. 1978. Udsolgt. Den uopslidelige lærebog. En indholdsanalyse af folkeskolens samfundslareb gger. Af Lise Togeby. 1978. $\mathrm{x}+220 \mathrm{~s} .45,00 \mathrm{kr}$. incl. moms.

Centralforvaltning $i$ seks vestlige lande. Af Hans Martens. 1978. 271 s. 45,00 kr. incl. moms.

De unges valgret. Af Palle Svensson. 1978. 172 s. Borgerdeltagelse og grasrodsbevægelser. Nogle nyere tendenser i dansk politik. Af Poul Erik Mouritzen i samarbejde med Niels Refslund Poulsen og Finn Breinholt Larsen. 1978. $134 \mathrm{~s}$.

Bøgerne kan bestilles via boghandelen eller direkte fra forlaget: FORLAGET POLI'TICA $v /$ Politica-Fonden Institut for Statskundskab Aarhus Universitet 8000 Arhus C 